\title{
lodine nutritional status of women in their first trimester of pregnancy in Catalonia
}

\author{
Maria Teresa Torres ${ }^{1,2,3,4^{*}}$, Lidia Francés ${ }^{5}$, Lluis Vila ${ }^{6}$, Josep María Manresa ${ }^{2,3,4} \mathbb{D}$, Gemma Falguera ${ }^{3,7}$, Gemma Prieto ${ }^{8}$, \\ Roser Casamitjana ${ }^{9}$, Pere Toran $^{2}$ and the IODEGEST study group
}

\begin{abstract}
Background: Sufficient iodine intake is needed during pregnancy to ensure proper fetal development. The iodine levels of women in their first trimester of pregnancy in Catalonia are currently unknown. This data would help to determine whether our public health services should establish recommendations or interventions in this line. The aim of this study was to investigate the iodine nutritional status, prevalence of urinary iodine $<150 \mu \mathrm{g} / \mathrm{L}$, and tobacco use in the first trimester of pregnancy in our setting.
\end{abstract}

Methods: Cross-sectional study. Data were collected during 2008-2009 from women in their first trimester at the primary care centers of the province of Barcelona (Spain). Pregnant women included in the study completed a questionnaire on eating habits and underwent urinary iodine concentration (UIC) assessment.

Results: Nine hundred forty five women completed the dietary questionnaire and urinary iodine testing. Median UIC was $172 \mu \mathrm{g} / \mathrm{L}$, with 407 participants (43.1\%) showing levels <150 $\mathrm{gg} / \mathrm{L}$. On multivariate logistic regression analysis, intake of $1-2$ glasses of milk per day, $\mathrm{OR}=0.63695 \% \mathrm{Cl}(0.45-0.90)$ or $>2$ glasses, $\mathrm{OR}=0.59395 \% \mathrm{Cl}$ (0.37-0.95); iodized salt consumption, $\mathrm{OR}=0.67895 \% \mathrm{Cl}(0.51-0.90)$; and use of iodine supplementation, $\mathrm{OR}=0.41095 \% \mathrm{Cl}(0.31-0.54)$, protected against the risk of $\mathrm{UIC}<150 \mu \mathrm{g} / \mathrm{L}$. Simultaneous consumption of iodized salt and milk ( $\geq 1$ glass/day) showed a larger protective effect: $\mathrm{OR}=0.427,95 \% \mathrm{Cl}(0.31-0.54)$.

Conclusion: The median UIC of the pregnant women surveyed indicated an acceptable iodine nutritional status according to the criteria established by the WHO and ICCIDD. The risk of urinary iodine $<150 \mu \mathrm{g} / \mathrm{L}$ decreased with simultaneous consumption of milk and iodized salt, similar to the decrease seen with iodine supplementation.

\section{Background}

A recent nationwide study conducted in Spain has reported that iodine nutrition is adequate in the general population, which showed a median urinary iodine concentration (UIC) of $117 \mu \mathrm{g} / \mathrm{L}$ [1]. Nonetheless, in the subgroup of women of childbearing age, median UIC was $114 \mu \mathrm{g} / \mathrm{L}$, a value indicating a situation of risk in pregnancy [1].

Iodine is an essential micronutrient that must be supplied by regular intake in the food consumed. It has a vital function in the synthesis of thyroid hormones, which act on several organs and body systems, and is especially

\footnotetext{
* Correspondence: torrescostamt@gmail.com

'Atenció a la Salut Sexual i Reproductiva (ASSIR), CAP Antoni Creus i Querol, Institut Català de la Salut, Terrassa, Barcelona, Spain

${ }^{2}$ Unitat de Suport a la Recerca Metropolitana Nord, Institut Universitari d'Investigació en Atenció Primària Jordi Gol (IDIAP Jordi Gol), Sabadell, Barcelona, Spain

Full list of author information is available at the end of the article
}

important for central nervous system development starting from the earliest stages of embryonic and fetal growth [2].

Iodine requirements vary with age and the individual's physiological condition. In pregnancy, thyroid metabolism undergoes a series of changes as the demand for iodine increases due to embryonic and fetal development. Since the early stages of pregnancy, the thyroid gland undergoes stimulation due to the effect of chorionic gonadotropin hormone [3]. There is an increase in the available blood volume and the iodine distribution space, iodine is transferred from the mother's circulatory system to the fetal-placental unit, and an increase in glomerular filtration leads to increasingly larger amounts of iodine being eliminated in urine $(30 \%-50 \%)$. This combination of factors results in a high demand for iodine during pregnancy [4-6]. During the first trimester, thyroid hormones for embryonic and fetal tissues rely exclusively on the available maternal hormones; hence, 
iodine deficiency in the mother may have a negative impact on prenatal development [7]. Clinical studies have reported a relationship of iodine deficiency and maternal hypothyroxinemia during pregnancy with impaired neurocognitive and psychological development of the children [3,8-13]. Therefore, it is important to increase iodine intake starting in the early stages of pregnancy and, if possible, even beforehand. The World Health Organization (WHO), together with the United Nations International Children's Emergency Fund (UNICEF) and the International Council for Control of Iodine Deficiency Disorders (ICCIDD), recommend a daily iodine intake of between 200 and $250 \mu \mathrm{g} /$ day during pregnancy [14].

Under normal conditions, there is a balance between iodine intake and urinary output, making the UIC a good indicator of recently consumed iodine [15]. The median UIC indicating optimum iodine intake in pregnant women is 150 to $250 \mu \mathrm{g} / \mathrm{L}[14,15]$. Studies carried out in various European countries, including Spain, have reported highly variable values, ranging from 60 to $250 \mu \mathrm{g} / \mathrm{L}$ [16].

Several strategies can be applied to ensure an adequate iodine supply and to correct deficiencies in this regard. The WHO and other international agencies have advocated universal salt iodization for worldwide consumption. In cases where iodine requirements cannot be guaranteed through diet during pregnancy, the WHO recommends potassium iodide supplementation [14].

Another aspect to include when considering the dietary and health habits of pregnant women is tobacco use and its impact on maternal thyroid function. Tobacco is considered a goitrogenic substance, as it inhibits thyroid uptake of iodine [17]. Tobacco use during pregnancy has been associated with changes in thyroid function in both the mother and fetus [18-20], and with changes in the UIC [21]. During lactation, tobacco use lowers the iodine content in breast milk [22].

Currently, there is little available data on the iodine nutritional status in pregnant woman in Catalonia (an autonomous region in northeast Spain) or the dietary habits that may be determinant in this regard. The available information comes from studies conducted in limited areas of our region or in women in the third term of pregnancy $[23,24]$. To fill this gap, the aim of this study was to determine the iodine status of a population of pregnant women during the first trimester of pregnancy-the time when thyroid deficiency can have the greatest impact on embryonic development-and to investigate the habits affecting the iodine status in this population in a large geographical area of Catalonia. The ultimate aim was to gain information that will be useful to assess the need for interventions in this population by a public health program.

\section{Methods \\ Design}

This is a cross-sectional descriptive study, based on information collected from women in their first trimester of pregnancy in 2008-2009. The information was obtained within the structure of a clinical trial whose ultimate purpose is to evaluate the effect of an intervention on eating habits and its benefits on iodine levels in pregnant women [25]. The present report describes the iodine status results in this population. The study was approved by the Clinical Research Ethics Committee at the Primary Care Research Institute (IDIAP) Jordi Gol.

\section{Setting}

The study was conducted within the framework of the primary care center Program for Sexual and Reproductive Health Care (PASSIR) of the Catalonia Central and Metropolitana Nord Regional Offices of the Institut Català de la Salut (ICS, Catalonian Institute of Health) in the province of Barcelona (Spain).

\section{Participants}

A consecutive recruitment was carried out within a clinical trial framework. During 2008 and 2009, all women older than 17 years who were seen in the participating centers in their first trimester of pregnancy ( $<13$ weeks) and accepted to participate were included in the study. Pregnant women with thyroid disease, no telephone contact, or difficulty communicating with the health personnel (cognitive, sensory, or language problems), and those refusing to participate, were excluded. A calculated sample size of 989 pregnant women was needed to answer the hypothesis of the clinical trial [25].

\section{Data collection}

The socio-demographic data included patient age, place of origin, place of residence (rural/urban), and educational level. Information on dietary and other habits was collected at a personal interview by midwives in the participating primary care centers, using a standardized questionnaire [25] showing good reliability (Cronbach's alpha, 0.960 and intraclass correlation coefficient, 0.927). The questionnaire contained items related to consumption of cow milk (glasses/day; 1 glass $=200 \mathrm{~mL}$ ), and fish (servings/week), regular consumption of iodized salt (Yes/No), daily use of iodine supplements (potassium iodide or iodine vitamin supplements) (Yes/No), use of iodinated antiseptics, and tobacco use.

Urinary iodine concentration $(\mu \mathrm{g} / \mathrm{L})$ was determined as follows: A first morning urine sample was collected from each woman, quickly frozen at $-40{ }^{\circ} \mathrm{C}$, and transported within 24 to $48 \mathrm{~h}$ to a central laboratory (Barcelona Hospital Clinic), where UIC determination was performed using the Benotti \& Benotti method [26]. Urine was first 
digested with chloric acid and then underwent the Sandell-Kolthoff reaction, in which iodine was determined by its action as a catalyst in the reduction of ceric ammonium sulphate in the presence of arsenious acid. The inter-assay and intra-assay coefficients of variation of the technique were $15.5 \%$ and $12.6 \%$, respectively. Three times a year, the UIC assay undergoes evaluation by an external quality assessment program from the Spanish Association of Neonatal Screening (AECNE). UIC values were dichotomized as $<150 \mu \mathrm{g} / \mathrm{L}$ (insufficient) and $\geq 150 \mu \mathrm{g} / \mathrm{L}$ (adequate) [14] in the analyses.

\section{Statistical analysis}

Quantitative variables are described as the mean and standard deviation or the median and first and third quartiles (Q1-Q3) for those with a non-normal distribution. Categorical variables are expressed as the absolute frequency and percentage.

The Student $t$ test for independent data and the Mann-Whitney $U$ test, as appropriate, were used for quantitative variables and the Pearson chi-square test for categorical variables.

A multivariate logistic regression model was performed, in which the dependent variable was UIC less than or equal to $150 \mu \mathrm{g} / \mathrm{L}$. The Initial model contained all the covariates that individually had an association with UIC according to a significance level of $p \leq 0.1$. The final model included statistically significant $(p<0.05)$ covariates, while also considering Akaike's information criterion and biological plausibility. Akaike's information criterion is a tool that balances the information provided by a set of variables (goodness of fit) and the principle of parsimony (use of the minimum possible set of variables, less complexity), making it useful for model selection.

All analyses were performed with SPSS for Windows, version 22.0. Significance was set at a $p$-value of $\leq 0.05$.

\section{Results}

In total, 985 pregnant women in their first trimester of pregnancy were recruited. We were able to obtain the urinary iodine concentration in 970 (98.5\%) women, and 945 (95.6\%) also answered the standardized questionnaire.

\section{Characteristics of the sample}

The mean age of the participants was 30.6 (4.6) years, and $784(83.0 \%)$ were Spanish. Most (696, 73.7\%) were from urban areas. The breakdown by educational level was as follows: $5(0.5 \%)$ had received no formal education, 28 (3.0\%) had not completed primary school, 232 (24.6\%) had completed primary school, 393 (41.6\%) had completed secondary school, and 287 (30.4\%) had a university degree. As to tobacco use, 221 (23.4\%) said that they were smokers and 98 (10.4\%) ex-smokers (had stopped smoking less than 1 year previously, including those who stopped in early pregnancy); 176 (20.4\%) women continued smoking during the first trimester of pregnancy.

\section{Urinary iodine concentration}

The median overall UIC [Q1-Q3] was $172 \mu \mathrm{g} / \mathrm{L}$ [103.8289.3]. UIC distribution is depicted in Fig. 1. Among the total of participants, $43.1 \%$ had a UIC $<150 \mu \mathrm{g} / \mathrm{L}$ and $8.8 \%$ a UIC $>600 \mu \mathrm{g} / \mathrm{L}$. Median UIC did not differ according to the women's place of residence (rural/urban), place of origin, education level, use of iodinated antiseptics (3.1\% of the population), or tobacco use (Table 1$)$. The Spearman rho correlation coefficient between the number of cigarettes smoked and UIC level was nil ( $r=-0.074$, $p=0.386)$. In total 337 (35.7\%) women reported using iodized salt. The median UIC was higher in this group than in nonusers (189 vs $158 \mu \mathrm{g} / \mathrm{L} ; p<0.001$ ) (Table 2 ). The 442 (46.8\%) women taking iodine supplementation also showed a higher median UIC than those who did not (209.5 vs $140 \mu \mathrm{g} / \mathrm{L} ; p<0.001$ We found that an increase in milk consumption was associated with a higher UIC (139.5, 176, and $198 \mu \mathrm{g} / \mathrm{L}$ for $0,1-2$, and $>2$ glasses/day, respectively; $p=0.003$ ). The median UIC showed no differences in relation to fish consumption.

\section{Association with UIC $<150 \mu \mathrm{g} / \mathrm{L}$}

Urinary iodine values were dichotomized into $<150 \mu \mathrm{g} / \mathrm{L}$ and $\geq 150 \mu \mathrm{g} / \mathrm{L} ; 407$ (43.1\%) women had values below $150 \mu \mathrm{g} / \mathrm{L}$ (Tables 1 and 2). On bivariate analysis, UIC $<150 \mu \mathrm{g} / \mathrm{L}$ showed no relationship with the women's place of residence (urban or rural), place of origin, education level, or smoking habit. However, higher milk consumption $(p=0.016)$, iodized salt use $(p<0.001)$, and iodine supplementation $(p<0.001)$ were associated with UIC $\geq 150 \mu \mathrm{g} / \mathrm{L}$ (Table 2). No associations were found between the UIC value and fish consumption or exposure to iodinated antiseptics.

\section{Multivariate analysis}

To determine which of the variables studied were associated with an insufficient UIC, multivariate logistic regression analysis was performed using UIC $<150 \mu \mathrm{g} / \mathrm{L}$ as the dependent variable and each of the sociodemographic variables and items on the dietary questionnaire as independent variables.

In Model 1, milk consumption had a protective effect on UIC $<150 \mathrm{mg} / \mathrm{L}$, which increased with increasing milk consumption from 1 to 2 to $>2$ glasses/day (OR 0.636 [0.45-0.90] and 0.593 [0.37-0.95], respectively). Iodine supplementation and iodized salt intake also provided a protective effect (OR 0.410 [0.31-0.54] and OR 0.678 [0.51-0.90], respectively) (Table 3 ).

In Model 2, daily consumption of 1 or more glasses of milk was combined with iodized salt use (Table 3). 


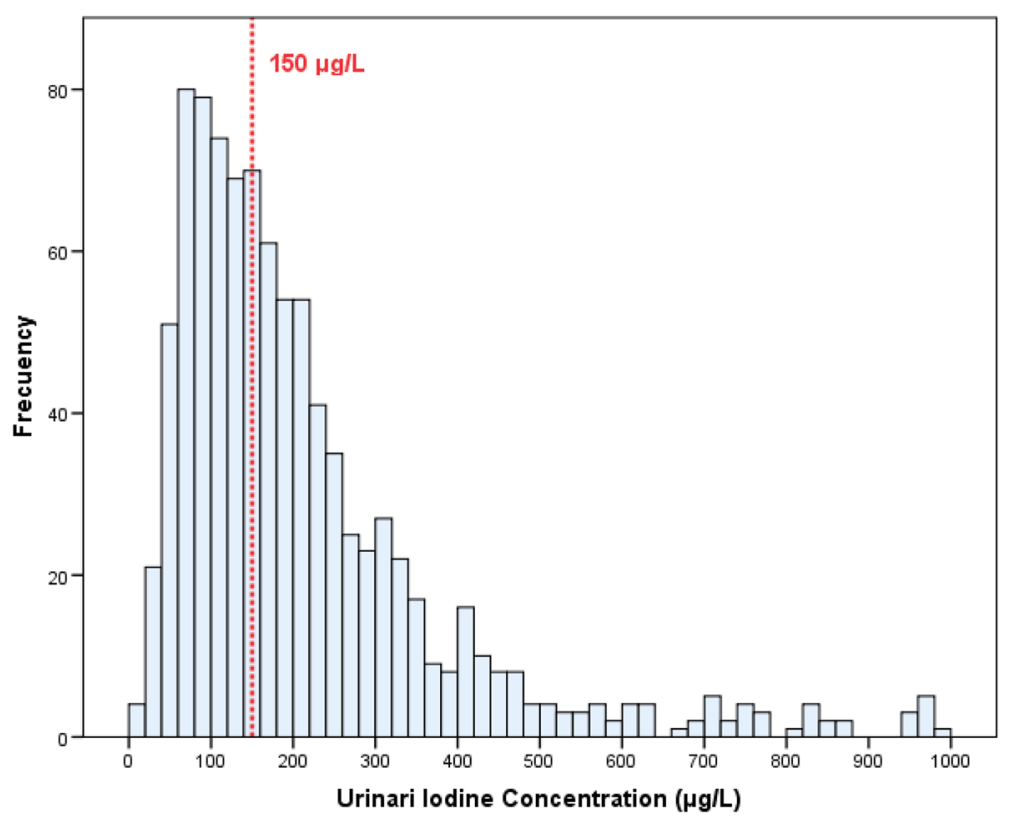

Fig. 1 Histogram of the iodine concentration in the urine of pregnant women in their first trimester of pregnancy. The discontinuous line indicates the value of urinary iodine recommended in pregnant women ( $\geq 150 \mathrm{mg} / \mathrm{dL})$. The $43.1 \%$ of these women had UIC $<150 \mathrm{mg} / \mathrm{dL}$

Table 1 Characteristics of pregnant women and related urinary iodine level

\begin{tabular}{|c|c|c|c|c|c|}
\hline & $\begin{array}{l}\text { Urinary lodine } \\
\geq 150 \mu \mathrm{g} / \mathrm{L}\end{array}$ & $\begin{array}{l}\text { Urinary lodine } \\
<150 \mu \mathrm{g} / \mathrm{L}\end{array}$ & $p^{a}$ & $\begin{array}{l}\text { Urinary iodine }(\mu \mathrm{g} / \mathrm{L}) \\
\text { Median [Q3-Q3] }\end{array}$ & $p^{b}$ \\
\hline TRIMESTER 1 & $n=556$ & $n=414$ & & $n=970$ & \\
\hline & & & & 172.0 [103.8-289.3] & - \\
\hline Age & $31.0(4.5)$ & $29.9(4.6)$ & $<0.001$ & - & - \\
\hline Place of residence & & & 0.526 & & 0.976 \\
\hline Urban & $413(57.9 \%)$ & $300(42.1 \%)$ & & $157.5[95.0-243.8]$ & \\
\hline Rural & $143(556 \%)$ & $114(44.4 \%)$ & & 154.0 [100.6-231.5] & \\
\hline Place of origin & & & 0.127 & & 0.335 \\
\hline Native of Spain & $448(57.1 \%)$ & $336(42.9 \%)$ & & 169.5 [102.2-287.5] & \\
\hline South America & $47(66.2)$ & $24(33.8 \%)$ & & $192.5[94.1-309.3]$ & \\
\hline Africa & 24 (46.2\%) & $28(53.8 \%)$ & & $145.5[95.3-211.3]$ & \\
\hline Other & 19 (50.0\%) & $19(50.0 \%)$ & & $135.0[85.0-249.0]$ & \\
\hline Educational level & & & 0.035 & & 0.623 \\
\hline Illiterate & $2(40.0 \%)$ & $3(60.0 \%)$ & & 85.0 [47.6-204.0] & \\
\hline Incomplete primary school & $13(46.4 \%)$ & $15(53.6 \%)$ & & $148.0[79.8-333.5]$ & \\
\hline Primary School & $126(54.3 \%)$ & $106(45.7 \%)$ & & 150.0 [103.5-238.5] & \\
\hline High School & $221(56.2 \%)$ & $172(43.8 \%)$ & & $154.0[95.5-232.0]$ & \\
\hline University degree & $176(61.3 \%)$ & $111(38.7 \%)$ & & $163.0[93.9-252.8]$ & \\
\hline Tobacco use & & & 0.253 & & 0.263 \\
\hline Non-smoker & $374(59.1 \%)$ & $259(40.9 \%)$ & & 181.0 [104.0-294.0] & \\
\hline Ex-smoker & $54(55.1 \%)$ & $44(44.9 \%)$ & & 168.0 [105.8-319.5] & \\
\hline Smoker & 123 (53.0\%) & $109(47.0 \%)$ & & $157.5[98.1-242.5]$ & \\
\hline
\end{tabular}


Table 2 lodine intake according to the questionnaire and related urinary iodine level

\begin{tabular}{|c|c|c|c|c|c|}
\hline & $\begin{array}{l}\text { Urinary lodine } \\
\geq 150 \mu \mathrm{g} / \mathrm{L}\end{array}$ & $\begin{array}{l}\text { Urinary lodine } \\
<150 \mu \mathrm{g} / \mathrm{L}\end{array}$ & $p^{c}$ & $\begin{array}{l}\text { Urinary iodine }(\mu \mathrm{g} / \mathrm{L}) \\
\text { Median }[\mathrm{Q} 1-\mathrm{Q} 3]\end{array}$ & $p^{d}$ \\
\hline TRIMESTER 1 & $N=538$ & $N=407$ & & $N=945$ & \\
\hline$\overline{\text { Milk }^{a}}$ & & & 0.016 & & 0.003 \\
\hline 0 glasses & $85(47.8 \%)$ & $93(52.2 \%)$ & & $139.5[88.7-230.0]$ & \\
\hline 1-2 glasses & $372(58.8 \%)$ & $261(41.2 \%)$ & & 176.0 [105.0-294.3] & \\
\hline$>2$ glasses & $81(60.4 \%)$ & $53(39.6 \%)$ & & 198.0 [115.0-316.0] & \\
\hline Fish $^{\text {b }}$ & & & 0.220 & & 0.926 \\
\hline Non-consumption & 31 (53.4\%) & $27(46.6 \%)$ & & 165.0 [95.8-336.0] & \\
\hline 1 serving & $136(55.5 \%)$ & $109(44.5 \%)$ & & 169.0 [104.0-282.5] & \\
\hline 2 servings & $163(56.2 \%)$ & $127(43.8 \%)$ & & 168.5 [98.9-307.0] & \\
\hline 3 servings & $115(57.5 \%)$ & $85(42.5 \%)$ & & 171.5 [104.2-261.2] & \\
\hline$>3$ servings & $93(61.2 \%)$ & $59(38.8 \%)$ & & 180.0 [101.2-295.0] & \\
\hline lodized salt & & & $<0.001$ & & 0.001 \\
\hline No & $321(52.8 \%)$ & $287(47.2 \%)$ & & 158.0 [95.3-278.0] & \\
\hline Yes & $217(64.4 \%)$ & $120(35.6 \%)$ & & 189.0 [116.5-305.0] & \\
\hline lodine supplements & & & $<0.001$ & & $<0.001$ \\
\hline No & $234(46.5 \%)$ & $269(53.5 \%)$ & & $140.0[84.0-221.0]$ & \\
\hline Yes & 304 (68.8\%) & 138 (31.2\%) & & 209.5 [131.0-342.0] & \\
\hline
\end{tabular}

alasses/day

${ }^{\mathrm{b}}$ Servings/week

'Pearson's chi-square test

${ }^{\mathrm{d}}$ Mann-Whitney $U$ test

Consumption of iodized salt alone was a protective factor, but was non-significant, likely because of the relatively small number of women who used this product (OR 0.704 [0.38-1.32]; $p=0.276$ ). However, intake of a single glass of milk yielded a protective effect (OR 0.641 [0.42-0.98]; $p=0.039$ ), which was even greater if complemented with iodized salt consumption (OR 0.0.427 $[0.27-0.66] ; p<0.001)$, in a manner similar to the effect of iodine supplementation (OR 0.411 [0.31-0.54]; $p<0.001)$.

\section{Discussion}

The median UIC of pregnant women in their first trimester $(172 \mu \mathrm{g} / \mathrm{L})$ indicated an adequate iodine nutritional status $(\geq 150 \mu \mathrm{g} / \mathrm{L})$ [14], although $43.1 \%$ of the sample showed values $<150 \mu \mathrm{g} / \mathrm{L}$. This overall finding is consistent with the results obtained in studies conducted in adults and children ( 4 and 6 years old) from Catalonia, which reported UICs indicative of adequate iodine nutrition [27-29]. In our study, iodine status of the pregnant women included did not differ according to the place of residence (rural or urban), place of origin (native or immigrant), education level, or tobacco use.

The median UIC we found $(172 \mu \mathrm{g} / \mathrm{L})$ was notably higher than that obtained in a study performed in 2010 by Alvarez-Pedrerol et al. in Sabadell, an area within the setting of our study. In total, 600 women in the third trimester were included and the median UIC was $104 \mu \mathrm{g} / \mathrm{L}$ [23]. These differences may be explained by the lower consumption of iodized salt in that population compared to our cohort (11.5\% vs $35.7 \%)$. In another study, including 267 pregnant women in the first trimester in two areas of Catalonia, 139 in a mountain area and 128 in coastal area, the median UIC was found to be higher (coastal area, $142 \mu \mathrm{g} / \mathrm{L}$ and mountain area $209 \mu \mathrm{g} / \mathrm{L}$ ); iodized salt was used by $36.4 \%$ and $58 \%$ of the women, respectively [24].

In a study including a sample of 1844 women in the first trimester of pregnancy from 3 areas of Spain (Valencia, Guipúzcoa, Sabadell), the median UIC was lower than $150 \mu \mathrm{g} / \mathrm{L}$ in Valencia and Sabadell, but not in Guipúzcoa [30]. In a study conducted in Toledo (Spain) including 525 pregnant women, the median UIC was $164 \mu \mathrm{g} / \mathrm{L}$ [31]. The women were divided into 3 groups: 69 pregnant women who did not use iodized salt or iodine supplementation, 75 pregnant women who used iodized salt but not supplementation, and 381 pregnant women who used potassium iodide supplementation. Median UICs in the three groups were $134.5 \mu \mathrm{g} / \mathrm{L}$, $146 \mu \mathrm{g} / \mathrm{L}$, and $183 \mu \mathrm{g} / \mathrm{L}$, respectively. In several studies, median UIC value $>150 \mu \mathrm{g} / \mathrm{L}$ was associated with iodine supplementation [30-34].

In most European countries, very low median UICs have been reported, often less than $100 \mu \mathrm{g} / \mathrm{L}[14,35]$, 
Table 3 Multivariate logistic regression analysis to determine the role of dietary intake and iodine supplementation on the risk of having an iodine level $<150 \mu \mathrm{g} / \mathrm{L}$

\begin{tabular}{llllll}
\hline & $\beta$ & SE & OR & {$[95 \% \mathrm{Cl}]$} & $p$ \\
\hline MODEL 1 & & & & & \\
Constant & 0.633 & - & - & - & - \\
Daily milk consumption & & & & & \\
No consumption & Reference & - & - & & - \\
1-2 glasses & -0.453 & 0.176 & 0.636 & {$[0.45-0.90]$} & 0.010 \\
$>$ 2 glasses & -0.522 & 0.239 & 0.593 & {$[0.37-0.95]$} & 0.029 \\
lodized salt intake & & & & & \\
No consumption & Reference & - & - & & - \\
consumption & -0.389 & 0.145 & 0.678 & {$[0.51-0.90]$} & 0.007 \\
lodine supplementation & & & & & \\
No consumption & Reference & - & - & & - \\
consumption & -0.890 & 0.138 & 0.410 & {$[0.31-0.54]$} & $<0.001$ \\
MODEL 2 & & & & & \\
Constant & 0.617 & - & - & - & - \\
lodized salt intake and daily milk consumption & & & - \\
No consumption & Reference & - & - & & - \\
Only lodized salt & -0.351 & 0.320 & 0.704 & {$[0.38-1.32]$} & 0.276 \\
Only Milk & -0.445 & 0.216 & 0.641 & {$[0.42-0.98]$} & 0.039 \\
lodized salt and Milk & -0.850 & 0.236 & 0.427 & {$[0.27-0.68]$} & $<0.001$ \\
lodine supplementation & & & & & \\
No consumption & Reference & - & - & & - \\
consumption & -0.888 & 0.138 & 0.411 & {$[0.31-0.54]$} & $<0.001$ \\
\hline
\end{tabular}

Result of exploratory multivariate logistic regression analysis. The dependent variable was determined by the presence of UIC $<150 \mu \mathrm{g} / \mathrm{L}$.

Model 1 shows the covariates that were statistically significant $(p<0.05)$, taking under consideration Akaike's information criterion and biological plausibility Model 2 was obtained by combining salt intake and milk in a single variable

with the exception of Switzerland, Sweden, Slovenia, and some parts of Germany [36-40],

In the present study, UIC analysis in women who did not take potassium iodide supplements revealed that iodized salt intake along with milk consumption was sufficient to maintain median UIC above $150 \mu \mathrm{g} / \mathrm{L}$ (Table 3), although neither milk nor iodized salt intake alone showed a relationship with this value.

Multivariate analysis disclosed the independent roles of intake of milk, iodized salt, and supplementation on the UIC. An association was found between milk consumption and the UIC, and when iodized salt intake was combined with this variable, protection against iodine levels $<150 \mu \mathrm{g} / \mathrm{L}$ was even higher, and similar to the protection obtained with supplementation (Table 3).

A similar association was detected in a recent study in northern Spain (Asturias): pregnant women who consumed 2 or more portions of dairy products per day had a UIC of $230 \mu \mathrm{g} / \mathrm{L}$, whereas those who consumed less had a level of $191 \mu \mathrm{g} / \mathrm{L}$. In addition, this study found a median UIC $\geq 150 \mathrm{mg} / \mathrm{L}$ in pregnant women who consumed iodized salt (41). In the study by Alvarez-Pedrerol et al., there was no association between the UIC and the foods included in their survey, with the exception of milk [23]. These authors also found that increases in milk consumption elicited a parallel increase in mean UIC values: 0 glasses/day, $78 \mu \mathrm{g} / \mathrm{L}$; $1-2$ glasses/day, $100 \mu \mathrm{g} / \mathrm{L}$; and $>2$ glasses/day, $117 \mu \mathrm{g} / \mathrm{L}$. A study in pregnant women conducted in the United Kingdom also revealed a significant positive association between milk consumption and the UIC [41]: The mean urinary iodine/urinary creatinine ratio value was $72 \mu \mathrm{g} / \mathrm{g}$ when milk consumption was $<140 \mathrm{~mL} /$ day, which rose to $150 \mu \mathrm{g} / \mathrm{g}$ when consumption was more than $280 \mathrm{~mL} /$ day.

In Spain, the effect of milk consumption on the UIC was first detected in a study carried out in children (415 years old) more than 10 years ago [42]. Other studies including a population of adults and children who did not consume iodized salt, reported a median UIC of more than $100 \mu \mathrm{g} / \mathrm{L}$ [24, 43-45], suggesting that other sources of iodine in addition to iodized salt were being consumed, such as dairy products. A recent analysis of 362 samples of milk from different parts of Spain showed a mean iodine level of $259( \pm 58) \mu \mathrm{g} / \mathrm{L}$ [46]. Furthermore, in a sample of more than 4000 Spaniards aged 18 years and older, there was a significant association between milk consumption at least once a day and a UIC $>100 \mu \mathrm{g} / \mathrm{L}$ [1]. Similar results were observed in a nationwide study conducted in a population of almost 2000 Spanish children [47]. The role of milk as a source of iodine, as was seen in Spain, is recognized in other European countries [48-53]. However, the "accidental iodination" of milk, such as that occurring in the United Kingdom [48], implies a risk of considerable variations in iodine content if there is no regulation and control. Australia has seen a drop in iodine nutrition due to a decreased iodine content in its milk supply $[54,55]$.

Iodized salt is the food traditionally recommended by the WHO and ICCIDD to ensure a proper level of iodine nutrition in the population [56]. The risk of iodine deficiency could be resolved if at least $90 \%$ of households consumed iodized salt. In Spain, however, iodized salt consumption in households is less than 50\% and in the case of pregnant women, 35.5\% [1]. As in other studies performed in our geographic area [23, 24], no association was found between fish consumption and the UIC in the pregnant women studied.

About $9 \%$ of our population had extreme UIC values $(>600 \mu \mathrm{g} / \mathrm{L})$. Although potassium iodide supplementation was higher in this group, it is difficult to attribute this to such a high UIC. However, seaweed consumption, application of iodized antiseptics in pregnancy [57], and use of salt with excessive iodination could justify UIC values $>600 \mathrm{mg} / \mathrm{dL}$. 
Some studies have reported an association between smoking and an increased risk of goiter or other thyroid problems $[18,20,24,51,58]$, but we did not find a significant effect of tobacco use on UIC values.

\section{Conclusion}

In conclusion, the overall median UIC of women in their first trimester of pregnancy found in our study is indicative of adequate iodine nutritional status according to the criteria established by the WHO and ICCIDD, although $43.1 \%$ were found to have suboptimal levels. Simultaneous consumption of iodized salt and milk was as effective as potassium iodide supplementation to achieve adequate iodine nutrition. The iodine concentration in salt in Spain $(60 \mathrm{ppm})$ and the high concentration of iodine in cow milk, which has increased in recent years, may explain these findings.

Women of childbearing age in our region should consume iodized salt and milk to maintain an optimal UIC, particularly those who are planning a pregnancy. A good intra-thyroidal deposit of iodine enables the gland to adapt and respond better to the physiologic changes that occur during pregnancy. If women use these iodine-rich products in the year before and during pregnancy, their iodine status will likely be adequate and iodine supplementation will not be necessary. Public health campaigns should be developed in our setting to promote consumption of iodized salt. Moreover, our national food agencies should ensure adequately iodized salt and regular monitoring of iodine content in milk.

\section{Additional file}

Additional file 1. lodegest Data Analysis. (XLSX 47 kb)

\section{Acknowledgements}

We wish to thank the pregnant women for participating as volunteers, and the midwives who collaborated in the data collection.

We appreciate the support provided by collaborators from The IODEGEST Study Group.

The IODEGEST Study Group

Montse Abella, Nuria Sampedro, Glòria Miralpeix, Montse Villanueva, Concepción Manzano, Judit Cos (PASSIR Sabadell); Pilar Soteras, Fermina Casas, Coloma Graells, Mireia Llucià, Rosalia Ibars (PASSIR Cerdanyola); Encarna López, Montserrat Manzanares, Irene Lorente, Eva Artieda, Meritxell Casajoana, Dolors Muñoz, Llucia Burgos, Angelica Hidalgo (PASSIR Mollet); Anna Fusté, Dolors Lladó, Rosa Subirats, Angelina Masoliver, Imma Trujillo, Rosa Banús, Dolors Salas, Montse Pujol, Dolors Grau, Roser Sanglas, Anabel Mayos (PASSIR Osona); Náyade Crespo, Rosa Codina, Rosa Forn, Montserrat Galí, Antonia Hidalgo, Teresa Macià, Mercè Vendrell, Montserrat Sallent, Montserrat Ribera, Rosa Oller, Teresa Riba, Esther Romero, Adelaida Expósito, Encarnació Santaeulàlia, Anna Vilaseca (PASSIR Bages); Dolors Guix, Gemma Olivera, Merche García, Rosa Sans, Marta Roman, Ma Jose Vila, Maite Martinez, Esther Serrano, Sonia Díaz, Carolina Alcaine, Susana Sancho, Remei Fenollosa, Encarna Gascón, Núria Risques, Araceli Santamaria, Remei Corominas, Xavi Espada, Maria Helena Perez, Concepción de la Fuente, Assumpta Prats, Maria Rosa Cabedo, Carme Magem, Mercedes Vigil, Carmen Biern, Montse Bach, Joana Relat. (PASSIR Granollers); Engracia Coll, Carmen Bayascas, Olga Ezquerro, Patricia Reategui, Anna Campos, Rosa Bach (PASSIR Mútua
Terrassa); Inés Molina, Eva Martinez, Anna Bartolí, Rosa Ferrer, Rocio Hernandez. (PASSIR Anoia).

\section{Funding}

This project was awarded a grant from the Spanish Ministry of Health, from the Carlos III Health Institute (PI 07/1265) and has been registered at the Trial Registration: Clinical Trials.gov (Identifier NCT01301768).

\section{Availability of data and materials}

Attached dataset as Additional file 1.

\section{Authors' contributions}

MTT have made substantial contributions to the conception and design, acquisition of data, analysis and interpretation of data. GF, GP have made substantial contributions to the conception and design. LF, LLV have made substantial contributions to the conception and design, and interpretation of data. All authors read and approved the final manuscript.

\section{Authors' information}

Not applicable.

\section{Ethics approval and consent to participate}

All women consent to participate. The study was approved by the Clinical Research Ethics Committee at the Primary Care Research Institute (IDIAP) Jordi Gol.

\section{Consent for publication}

Not applicable.

\section{Competing interests}

The authors declare that they have no conflicts of interest.

\section{Publisher's Note}

Springer Nature remains neutral with regard to jurisdictional claims in published maps and institutional affiliations.

\section{Author details}

${ }^{1}$ Atenció a la Salut Sexual i Reproductiva (ASSIR), CAP Antoni Creus i Querol, Institut Català de la Salut, Terrassa, Barcelona, Spain. ${ }^{2}$ Unitat de Suport a la Recerca Metropolitana Nord, Institut Universitari d'Investigació en Atenció Primària Jordi Gol (IDIAP Jordi Gol), Sabadell, Barcelona, Spain. ${ }^{3}$ GRASSIR research group, IDIAP Jordi Gol, Generalitat de Catalunya, Barcelona, Spain. ${ }^{4}$ Departament d'Infermeria, Universitat Autònoma de Barcelona, Bellaterra, Cerdanyola del Vallès, Spain. ${ }^{5}$ Departament d'Infermeria, Universitat de Barcelona, L'Hospitalet de Llobregat, Barcelona, Spain. ${ }^{6}$ Servicio de Endocrinología y Nutrición, Hospital de Sant Joan Despí 'Moisès Broggi', Sant Joan Despí, Barcelona, Spain. ${ }^{7}$ Atenció a la Salut Sexual i Reproductiva (ASSIR) Gerència Territorial Metropolitana Nord, Institut Català de la Salut, Sabadell, Barcelona, Spain. ${ }^{8}$ Gerencia de Atención Primaria, Ávila, Spain. ${ }^{9}$ Centro de Diagnóstico Biomédico - Bioquímica y Genética Molecular, Hospital Clínic, Barcelona, Spain.

Received: 9 September 2016 Accepted: 18 July 2017

Published online: 26 July 2017

\section{References}

1. Soriguer F, García-Fuentes E, Gutierrez-Repiso C, Rojo-Martínez G, Velasco I, Goday A, Bosch-Comas A, Bordiú E, Calle A, Carmena R, Casamitjana R, Castaño L, Castell C, Catalá M, Delgado E, Franch J, Gaztambide S, Girbés J, Gomis R, Gutiérrez G, López-Alba A, Martínez-Larrad MT, Menéndez E, Mora-Peces I, Ortega E, Pascual-Manich G, Serrano-Rios M, Valdés S, Vázquez JA, Vendrell J. lodine intake in the adult population. Di@bet.Es study. Clin Nutr. 2012;31:882-8.

2. Morreale de Escobar G, Escobar del Rey F. Metabolismo de las hormonas tiroideas y el yodo en el embarazo. Razones experimentales para mantener una ingesta de yodo adecuada en la gestación. Endocrinol y Nutr. 2008;55(Supple):7-17.

3. Glinoer $\mathrm{D}$. The regulation of thyroid function during normal pregnancy: importance of the iodine nutrition status. Best Pract Res Clin Endocrinol Metab. 2004;18:133-52. 
4. Glinoer D. The importance of iodine nutrition during pregnancy. Public Heal Nutr. 2007;10:1542-6.

5. Donnay Candil S. Uso racional del yoduro potásico durante el embarazo y la lactancia. Endocrinol y Nutr. 2008;55(Supple):29-34.

6. Delange F. Optimal iodine nutrition during pregnancy, lactation and the neonatal period. Int J Endocrinol Metab. 2004:2:1-12.

7. Morreale de Escobar G, Obregon M, Escobar del Rey F. Maternal thyroid hormones early in pregnancy and fetal brain development. Best Pract Res Clin Endocrinol Metab. 2004;18:225-48.

8. Morreale de Escobar G, Obregon MJ, Escobar del Rey F. Role of thyroid hormone during early brain development. Eur J Endocrinol. 2004;151(Suppl):U25-37.

9. Zimmermann MB. The role of iodine in human growth and development. Semin Cell Dev Biol. 2011;22:645-52.

10. Velasco I. Anomalías prenatales asociadas a la deficiencia de yodo. Progr Diag Trat Prenat. 2005;17:123-8.

11. Vermiglio F, Lo Presti VP, Moleti M, Sidoti M, Tortorella G, Scaffidi G, Castagna MG, Mattina F, Violi MA, Crisà A, Artemisia A, Trimarchi F. Attention deficit and hyperactivity disorders in the offspring of mothers exposed to mild-moderate iodine deficiency: a possible novel iodine deficiency disorder in developed countries. J Clin Endocrinol Metab. 2004;89:6054-60.

12. Berbel P, Mestre IL, Santamaria A, Palazon I, Franco A, Graells M, GonzalezTorga A, de Escobar GM. Delayed neurobehavioral development in children born to pregnant women with mild hypothyroxinemia during the first month of gestation: the importance of early iodine supplementation. Thyroid. 2009;19:511-9.

13. Henrichs J, Bongers-Schokking JJ, Schenk JJ, Ghassabian A, Schmidt HG, Visser TJ, Hooijkaas H, de Muinck K-SSMPF, Hofman A, Jaddoe WW, Visser W, Steegers EAP, Verhulst FC, de Rijke YB, Tiemeier H. Maternal thyroid function during early pregnancy and cognitive functioning in early childhood: the generation R study. J Clin Endocrinol Metab. 2010;95:4227-34.

14. ICCIDD: lodine requeriments in pregnancy and infancy. 2007;:1-2. https:// www.thyroid.org/wp-content/uploads/professionals/education/IDD_NL_ Feb07.pdf. Accessed 22 July 2017.

15. Laurberg P, Andersen S, Bjarnadottir RI, Carle A, Hreidarsson A, Knudsen N, Ovesen L, Pedersen I, Rasmussen L. Evaluating iodine deficiency in pregnant women and young infants-complex physiology with a risk of misinterpretation. Public Heal Nutr. 2007;10:1547-52.

16. Puig-Domingo M, Vila L. lodine status, thyroid and pregnancy. Hot Thyroidol. 2010; (5/10). http://www.ibrarian.net/navon/paper/lodine_ status_thyroid_and_pregnancy.pdf?paperid=19279198.

Accessed 22 July 2017.

17. Bertelsen $\mathrm{JB}$, Hegedüs L. Cigarette smoking and the thyroid. Thyroid. 1994:4:327-31

18. Männistö $T$, Hartikainen $A L$, Vääräsmäki M, Bloigu A, Surcel HM, Pouta $A$, Järvelin MR, Ruokonen A, Suvanto E. Smoking and early pregnancy thyroid hormone and anti-thyroid antibody levels in euthyroid mothers of the Northern Finland Birth Cohort 1986. Thyroid. 2012;22(9):944-50.

19. McDonald SD, Walker MC, Ohlsson A, Murphy KE, Beyene J, Perkins SL. The effect of tobacco exposure on maternal and fetal thyroid function. Eur $J$ Obstet Gynecol Reprod Biol. 2008;140:38-42.

20. Shields B, Hill A, Bilous M, Knight B, Hattersley AT, Bilous RW, Vaidya B. Cigarette smoking during pregnancy is associated with alterations in maternal and fetal thyroid function. J Clin Endocrinol Metab. 2009;94:570-4.

21. Vanderver GB, Engel A, Lamm S. Cigarette smoking and iodine as hypothyroxinemic stressors in U.S. women of childbearing age: a NHANES III analysis. Thyroid. 2007;17:741-6.

22. Laurberg $\mathrm{P}$, Nøhr SB, Pedersen KM, Fuglsang E. lodine nutrition in breast-fed infants is impaired by maternal smoking. J Clin Endocrinol Metab. 2004;89:181-7.

23. Alvarez-Pedrerol M, Ribas-Fito N, Garcia-Esteban R, Rodriguez A, Soriano D, Guxens M, Mendez M, Sunyer J. lodine sources and iodine levels in pregnant women from an area without known iodine deficiency. Clin Endocrinol. 2010;72:81-6.

24. Vila L, Serra-Prat M, de Castro A, Palomera E, Casamitjana R, Legaz G, Barrionuevo C, Munoz JA, Garcia AJ, Lal-Trehan S, Garcia A, Duran J, Puig-Domingo M. lodine nutritional status in pregnant women of two historically different iodine-deficient areas of Catalonia, Spain. Nutrition. 2011;27:1029-33

25. Prieto G, Torres MT, Francés L, Falguera G, Vila L, Manresa JM, Casamitjana R, Barrada JR, Acera A, Guix D, Torrent A, Grau J, Torán P. Nutritional status of iodine in pregnant women in Catalonia (Spain): study on hygiene-dietetic habits and iodine in urine. BMC Pregnancy Childbirth. 2011;11:17.
26. Pino S, Fang SL, Braverman LE. Ammonium persulfate: a new and safe method for measuring urinary iodine by ammonium persulfate oxidation. Exp Clin Endocrinol Diabetes. 1998;106(Suppl):S22-7.

27. Serra-Prat M, Diaz E, Verde Y, Gost J, Serra E, P-D M. Prevalence of iodine deficiency and related factors in 4 year-old schoolchildren. Med Clin. 2003;120:246-9.

28. Vila L, Castell C, Wengrovicz S, de L N, Casamitjana R. Estudio de la yoduria de la poblacion catalana adulta. Med Clin. 2006;127:730-3.

29. Capdevila Bert R, Marsal Mora JR, Pujol Salud J, Anguera Farran R. Prevalence study of iodine deficiency in a 6-year-old school population. An Pediatr. 2010;72:331-8.

30. Rebagliato M, Murcia M, Espada M, Alvarez-Pedrerol M, Bolumar F, Vioque J, Basterrechea M, Blarduni E, Ramon R, Guxens M, Foradada CM, Ballester F, Ibarluzea J, Sunyer J. lodine intake and maternal thyroid function during pregnancy. Epidemiology. 2010;21:62-9.

31. Marco A, Vicente A, Castro E, Eva PC, Rodriguez O, Merchan MA, Sastre J, Canovas B, Maqueda E, Pena V, Lopez J. Patterns of iodine intake and urinary iodine concentrations during pregnancy and blood thyroid-stimulating hormone concentrations in the newborn progeny. Thyroid. 2010;20:1295-9.

32. Santiago P, Berrio M, Olmedo P, Velasco I, Sanchez B, Garcia E, Martinez J, Soriguer $F$. Reference values for thyroid hormones in the population of pregnant women in Jaen (Spain). Endocrinol Nutr. 2011;58:62-7.

33. Jaen Diaz Jl, Lopez de Casto F, Cordero Garcia B, Santillana Balduz F, Martin Dal Gesso C. Thyroid disorders and iodine nutritional status in the first trimester of pregnancy. Endocrinol Nutr. 2008:55:196-201.

34. Santiago P, Velasco I, Muela JA, Sánchez B, Martínez J, Rodriguez A, Berrio M, Gutierrez-Repiso C, Carreira M, Moreno A, García-Fuentes E, Soriguer F. Infant neurocognitive development is independent of the use of iodised salt or iodine supplements given during pregnancy. Br J Nutr. 2013;110(5):831-9.

35. Zimmermann $M$, Delange F. lodine supplementation of pregnant women in Europe: a review and recommendations. Eur J Clin Nutr. 2004;58:979-84.

36. Zimmermann MB, Aeberli I, Torresani T, Burgi H. Increasing the iodine concentration in the Swiss iodized salt program markedly improved iodine status in pregnant women and children: a 5-y prospective national study. Am J Clin Nutr. 2005;82:388-92.

37. Andersson M, Aeberli I, Wust N, Piacenza AM, Bucher T, Henschen I, Haldimann M, Zimmermann MB. The Swiss iodized salt program provides adequate iodine for school children and pregnant women, but weaning infants not receiving iodine-containing complementary foods as well as their mothers are iodine deficient. J Clin Endocrinol Metab. 2010;95:5217-24.

38. Elnagar B, Eltom A, Wide L, Gebre-Medhin M, Karlsson FA. lodine status, thyroid function and pregnancy: study of Swedish and Sudanese women. Eur J Clin Nutr. 1998;52:351-5.

39. Fister P, Gaberscek S, Zaletel K, Krhin B, Gersak K, Hojker S. Thyroid volume changes during pregnancy and after delivery in an iodine-sufficient Republic of Slovenia. Eur J Obs Gynecol Reprod Biol. 2009;145:45-8.

40. Buhling KJ, Schaff J, Bertram H, Hansen R, Muller C, Wascher C, Heinze T, Dudenhausen JW. Supply of iodine during pregnancy-an inventory in Berlin, Germany. Z Geburtshilfe Neonatol. 2003;207:12-6.

41. Bath SC, Furmidge-Owen VL, Redman CW, Rayman MP. Gestational changes in iodine status in a cohort study of pregnant women from the United Kingdom: season as an effect modifier. Am J Clin Nutr. 2015;101:1180-7.

42. Millon JM, Soriguer F, Munoz R, Mancha I, Gomez-Huelga R, Goiburu E, Garcia-Almeida JM, Gonzalez-Romero S, Rojo-Martinez G. Determinant factors of ioduria in a scholar population in the south of Spain. Endocrinol $y$ Nutr. 2001:48:104-9.

43. Vila Ballester LL, Subirats Bayego E, Vila Subirana T, Margalef Mir N, Vallescar $\mathrm{R}$, de Leiva A. An endemic goiter study of a population in the Pyrenees (Cerdanya-Girona). An Med Interna. 1999;16:338-44.

44. Peris RB, Atienzar HN, Merchante Alfaro AA, Calvo RF, Tenias Burillo JM, Selfa MS, Lopez Garcia MJ. Bocio endemico y deficit de yodo: ¿sigue siendo una realidad en España? An Pediatr. 2006;65:234-40.

45. Delgado E, D-C FJ, Tarton T, ML B, MM V. Erradicacion de los trastornos por deficiencia de yodo en Asturias (España): 18 años de yodoprofilaxis con sal. Endocrinol y Nutr. 2004:51:492-6.

46. Soriguer F, Gutierrez-Repiso C, Gonzalez-Romero S, Olveira G, Garriga MJ, Velasco I, Santiago P, de Escobar GM, Garcia-Fuentes E. lodine concentration in cow's milk and its relation with urinary iodine concentrations in the population. Clin Nutr. 2011;30:44-8.

47. Vila L, Donnay S, Arena J, Arrizabalaga JJ, Pineda J, Garcia-Fuentes E, García-Rey C, Marín JL, Serra-Prat M, Velasco I, López-Guzmán A, Luengo LM, Villar A, Muñoz Z, Bandrés O, Guerrero E, Muñoz JA, Moll G, Vich F, Menéndez E, Riestra 
M, Torres Y, Beato-Vibora P, Aguirre M, Santiago P, Aranda J, Gutiérrez-Repiso C. lodine status and thyroid function among Spanish schoolchildren aged 6-7 years: the Tirokid study. Br J Nutr. 2016;115:1623-31.

48. Phillips DI. lodine, milk, and the elimination of endemic goitre in Britain: the story of an accidental public health triumph. J Epidemiol Community Heal. 1997;51:391-3.

49. Girelli ME, Coin P, Mian C, Nacamulli D, Zambonin L, Piccolo M, Vianello-Dri A, Gottardo F, Busnardo B. Milk represents an important source of iodine in schoolchildren of the Veneto region, Italy. J Endocrinol Investig. 2004;27:709-13.

50. Lamberg BA. Endemic goitre in Finland and changes during 30 years of iodine prophylaxis. Endocrinol Exp. 1986;20:35-47.

51. Rasmussen LB, Ovesen L, Bulow I, Jorgensen T, Knudsen N, Laurberg P, Pertild H. Dietary iodine intake and urinary iodine excretion in a Danish population: effect of geography, supplements and food choice. Br J Nutr. 2002;87:61-9.

52. Zamrazil V, Bilek R, Cerovska J, Delange F. The elimination of iodine deficiency in the Czech Republic: the steps toward success. Thyroid. 2004;14:49-56.

53. Dahl L, Opsahl JA, Meltzer HM, Julshamn K. lodine concentration in Norwegian milk and dairy products. Br J Nutr. 2003;90:679-85.

54. Li M, Waite KV, Ma G, Eastman CJ. Declining iodine content of milk and reemergence of iodine deficiency in Australia. Med J Aust. 2006;184:307.

55. Li M, Eastman CJ, Waite KV, Ma G, Zacharin MR, Topliss DJ, Harding PE, Walsh JP, Ward LC, Mortimer RH, Mackenzie EJ, Byth K, Doyle Z. Are Australian children iodine deficient? Results of the Australian National lodine Nutrition Study. Med J Aust. 2006;184:165-9.

56. WHO, ICCIDD, UNICEF: Assessment of iodine deficiency disorders and monitoring their elimination. A guide for programme managers. http://whqlibdoc.who.int/publications/2007/9789241595827_eng.pdf. 2007 (Thirst). Accessed 22 July 2017.

57. Velasco I, Naranjo S, Lopez-Pedrera C, Garriga MJ, Garcia-Fuentes E, Soriguer F. Use of povidone-iodine during the first trimester of pregnancy: a correct practice? BJOG. 2009;116:452-5.

58. Chanoine JP, Toppet V, Bourdoux P, Spehl M, Delange F. Smoking during pregnancy: a significant cause of neonatal thyroid enlargement. Br J Obs Gynaecol. 1991;98:65-8.

\section{Submit your next manuscript to BioMed Central and we will help you at every step:}

- We accept pre-submission inquiries

- Our selector tool helps you to find the most relevant journal

- We provide round the clock customer support

- Convenient online submission

- Thorough peer review

- Inclusion in PubMed and all major indexing services

- Maximum visibility for your research

Submit your manuscript at www.biomedcentral.com/submit

) Biomed Central 